\title{
Teaching Reform of International Students in China: From the Perspective of Promoting Political Ideology of Socialism with Chinese Characteristics
}

\author{
Shurong Zhao \\ School of Public Administration, \\ University of Electronic Science and Technology of China, \\ Sichuan, China
}

\author{
Shanshan Chen, Wenxue Fan \\ School of Public Administration, \\ University of Electronic Science and Technology of China, \\ Sichuan, China
}

\begin{abstract}
The curriculum "Globalization and World Politics" is guided by the 2015-2017 Action Plan for International Students and aims at cultivating talents with Chinese spirits, international vision and abilities of international competition and cooperation. The curriculum intends to conduct teaching reform for international students in China and incorporates materials with political ideology of socialism with Chinese characteristics into textbooks which could embody Chinese context. In addition, case teaching method and immersive teaching method are applied to stimulate students' initiatives and enthusiasm to optimize the course teaching methodology. The results we obtained demonstrate that the successful lessons of teaching reform have sublimated international students' Chinese spirits and provided resources support for the development of China's diplomacy and the "going global" strategy. Finally, the research puts forward four sugge stions to further implement the teaching reform.
\end{abstract}

Keywords-international students in China; political ideology of socialism with Chinese characteristics; textbook reform; case teaching method; immersive teaching method

\section{INTRODUCTION}

As an integral part of the opening up of China's education, international students studying in China have made tremendous contributions to China's reform and opening up as well as the modernization process. Under the new situation both at home and abroad, the opportunities and challenges facing China's education are coexisting. In order to implement the decisions of the Central Government on international students' education, the Ministry of Education, the Ministry of Foreign Affairs, the Ministry of Public Security, the Ministry of Finance and the Ministry of Human Resources and Social Security have formulated the 2015-2017 Action Plan for International Students. According to the plan, requirements for the education of foreign students in China including: (1) It is necessary to train a group of talents with international vision who are familiar with international rules and can participate in international cooperation and competition; (2) Cultivate more qualified people with Chinese spirits, international vision and abilities of international competition and cooperation, then attract a large number of international talents to provide resources for the development of China's diplomacy and the

This research is financed by:

(1) 2015 High Quality Textbook Construction for International Students in

China (Project No.: Y03003023901002142)

(2) 2016 MOOC Course Globalization and World Politics

(Project No. Y03094023701019460) “going global” strategy ${ }^{[1]}$; (3) Brand-based English courses for international students should be constructed so as to strengthen the construction of courses and teaching materials system, as well as improve the teaching content and methods to carry out teaching reform in foreign languages.

At present, there is a lack of Chinese-English textbooks with Chinese characteristics aimed at international students in China. Some textbooks completely copied materials of foreign scholars in the cultivation of foreign students in China. Teaching contents concerning China's national conditions have also copied foreign textbooks, ignoring the reality of China's social, economic and cultural development, resulting in the distortion of teaching information. As a result, students can not truly and comprehensively understand the lecture which makes it difficult to develop a high level of overseas students required by 2015-2017 Action Plan for International Students. Therefore, it is increasingly significant to establish new brand of lecture in English with the political ideology of socialism with Chinese characteristics based on national conditions of China, in order to carry out the teaching reform for international students in China, and train more international talents with Chinese spirits, international vision and abilities of international competition and cooperation.

As a key construction institute of nation's Project 985 , University of Electronic Science and Technology of China (UESTC) actively responds to the call of "Thirteen Five Year Plan” concerning education for international students"Expand the Scale of International Students and Improve the Training Level". The construction of English curriculum is one of the most important steps in the establishment of the quality assurance system for international students' education. The construction of an international high-level curriculum and research projects for postgraduates is an important measure for UESTC to establish an international education curriculum platform. The curriculum reform "Globalization and World Politics" aims to cultivate a group of talents who are familiar with international rules and can participate in international cooperation and competition, by making comparative study of the behaviors, features, political ideology of nations and international organizations. Meanwhile, lectures containing China's political system and international participation are held for international students to know more about China. 


\section{The Approaches to Promote Political Ideology of SOCIALISM WITH CHINESE CHARACTERISTICS AMONG INTERNATIONAL STUDENTS}

For the purpose of carrying forward the political ideology of socialism with Chinese characteristics in the education of overseas students in China, the reform should be deepened including the teaching materials compilation and teaching methods.

\section{A. Incorporate political ideology of socialism with Chinese characteristics into teaching materials}

At present, there is a lack of Chinese-English teaching materials aimed at international students with Chinese characteristics ${ }^{[2]}$. Most teaching materials contain contents of western countries, which are out of the reality of China's economic, cultural and social development and make it difficult to train students to become international talents. In order to overcome this drawback, the course "Globalization and World Politics" involves international political theories and complicated international issues. In this course, the teaching reform should be based on China's national conditions and introduce the political ideology of socialism with Chinese characteristics so that foreign students could understand China's role in globalization and world politics, which would help them acquire more comprehensive knowledge of globalization and world politics to improve their learning outcomes.

The curriculum reform "Globalization and World Politics" for foreign students in China made great progress in the compilation of teaching materials. Published by UESTC Press and edited by Professor Zhao Shurong, the book "Globalization and World Politics" introduced the international political theories in the process of globalization based on China's national conditions, introducing the economic, political and diplomatic conditions and prospects of major international forces through cases, accurately grasping the status and role of China in the international community, exploring the current international political structure and future developing trend ${ }^{[3]}$.

For example, (1) in chapter "Globalization”, a section titled "Globalization and China" is compiled based on the political ideology of socialism with Chinese characteristics, and China's role in the process of globalization is introduced, especially the positive role in foreign trade, foreign investment, information technology transfer and population migration. This part will enable foreign students to correctly assess China's position in globalization. (2) In chapter "World Politics", the section entitled "Contemporary World Politics and the Role of China” points out four characteristics of contemporary world politics, namely the negative impact of globalization is increasingly evident; the issue of nontraditional security is increasingly significant; imbalances of economic development have become prominent; the religious forces and nationalism have recovered worldwide; the center of power and wealth and the impetus for growth are shifting; and major changes will exist in international order. Meanwhile, according to these four characteristics, this chapter analyzes China's strategy based on the political ideology of socialism with Chinese characteristics. That is, Chinese government has proposed a political theory that emphasizes scientific development and social harmony in order to cope with the drawbacks of globalization and non-traditional security. As an ancient civilization, China has witnessed a great deal of turmoil in the global ideology and cultural innovations. China advocates the integration of civilizations and cultures, does not support separation, hostility or ethnic split, nor does it support the resolution of religions, denominations, or ethnic conflicts. China is committed to promoting global harmony. China persists in the policy of non-alignment and maintains cooperation and the opening-up policy for all countries in the transfer of global wealth and power. China will adhere to the current order of and international rules, which would contribute to stabilizing international politics and economy. (3) In chapter "classical theories of world politics", the section "Marx's Theory of Political Theories with Chinese Characteristics" is compiled. From the perspective of the development history of Marxism and the characteristics of contemporary socialism, the historical forms of Marxism and socialism are specifically discussed, which reflected China's historical process of deepening reform and opening up so that foreign students in China can have a comprehensive and indepth understanding of the political concept of socialism with Chinese characteristics.

\section{B. Adopt various teaching methods to promote the political philosophy of socialism}

Teaching methods refers to ways of implementing teaching syllabus and teaching content, and ways of teaching methods to promote the political ideology of socialism with Chinese characteristics. In the curriculum reform for overseas students in "Globalization and World Politics", the innovation has been carried out to form a teaching method system combining student idea, discussion, and openness, which could effectively help students learn autonomously and creatively.

First, introduce case teaching method. Case teaching method refers to organizing students to learn, conduct research and improve ability according to the teaching objectives and content requirements under the guidance of teachers ${ }^{[4]}$, as well as the method of examining students' academic performance and ability "5]. In the course "Globalization and World Politics", the current hot issues and major practices are introduced to integrate teaching contents and practical training. Case teaching method successfully builds a new dual-subject teaching model. On the arrangement of teaching content, the content of theory should be appropriately weakened, but the case study on China should be strengthened. While cultivating and developing students' critical thinking ability, students should be trained to conduct academic analysis and develop problem-solving skills. For example, in chapter "International Historical Development", the case analysis of major events in China during World War II is introduced. The after-class team work and group presentation could deepen students' understanding of Chinese political theory.

Second, introduce immersive teaching method. In 1975, American psychologist Dr. Mihaly Csikszentmihalyi proposed immersive theory in his research. He pointed out that when people dedicate themselves to something, they would neglect 
other disturbances and obtain the best learning outcomes ${ }^{[6]}$. Gagné, an American educational psychologist, pointed out that learning requires both internal and external conditions. Situations of learning are the external conditions that lead to the occurrence of learning events, and the intrinsic state and characteristics of learners are the internal conditions of learning. Analyzing the learning state through immersive theory can help construct a learning situation that encourages people to dedicate themselves to certain activities ${ }^{[7]}$.

Immersive learning emphasizes an autonomous, active and personalized learning right, which helps the individual generate a strong desire then achieve sustained motivation to learn, and can vividly express what he learned. This initiative learning is called "the immersion of learning". By adopting active learning methods with information and learning materials, students could complete the learning process, thus acquiring "learning memory" by leaps and bounds. For example, in the curriculum reform of "Globalization and World Politics”, teachers simulate grass-roots democratic election in rural areas so as to enable students to play roleplaying games and simulate the process of rural grass-roots electoral system. Therefore, foreign students in China can personally experience the construction of rural grass-roots democracy and its effectiveness as well as problems. In this way, students could achieve autonomous, active, personalized immersion learning to deepen the understanding of the political ideology of socialism with Chinese characteristics.

\section{Improve the Moral Education Quality and Cross-cultural Awareness of Teachers with Political Ideology of \\ Socialism with Chinese Characteristics}

As a teacher of foreign students in China, there are special requirements to be followed in addition to the basic professional ethics. The education of overseas students in China is not just the "process of knowledge acquisition". Its essence is humanistic and cross-cultural education which requires teachers a higher level of professional skills and ability to analyze, judge, communicate in order to help students correctly understand the political ideology of socialism with Chinese characteristics, abandon the negative impact of decadent culture. Teachers should conscientiously study and master the political ideology of socialism with Chinese characteristics. On the one hand, they are supposed to raise their awareness of moral cultivation and cross-cultural education. On the other hand, they should learn how to impart the political ideology of socialism with Chinese characteristic. Teachers should pay attention to students' learning process to give guidance. Vivid and interesting course could significantly stimulate the enthusiasm of international students in studying Chinese culture. They not only improve their professional skills, but also cultivate Chinese spirits.

\section{The Result of TeAching Reform of International StUdents IN ChINA FROM THE PERSPECTIVE OF PROMOTING Political IDEOLOGY OF SOCIALISM WITH CHINESE CHARACTERISTICS}

This research conducts a questionnaire survey on international students taking the course "Globalization and World Politics" in UESTC to reflect the achievements of the teaching reform. The result of teaching reform has reference value: (1) 73\% of international students in China said they can fully understand the relevant contents of China's basic national conditions from the textbook of "Globalization and World Politics”, 15\% of international students think that they have a basic understanding of China's national conditions, and $12 \%$ of them think that they have a general understanding of China's basic national conditions. None of them believe that teaching materials on "Globalization and World Politics" cannot help them understand China's basic national conditions. (2) 59\% of international students can fully understand China's role in the process of globalization from the teaching materials of "Globalization and World Politics", and 24\% of foreign students have a general understanding about China's role in the process of globalization (3) $64 \%$ of the students said that they can fully understand China's position and role in the political system of the contemporary world from "Globalization and World Politics", and 21\% of the students said that they know more about China's position and role than before; (4) More than $80 \%$ of the foreign students said that they can learn more about the political theories with Chinese characteristics and international issues facing China from "Globalization and World Politics"; (5) More than 90\% of overseas students said case-based analysis and immersive teaching methods can further deepen their understanding of the political ideology of socialism with Chinese characteristics. Only less than $20 \%$ of students are more satisfied with traditional teaching methods. From the above findings, it can be concluded that in carrying out the teaching reform of international students in the course "Globalization and World Politics”, achievements have been made on reaching the goal of promoting the political ideology of socialism with Chinese characteristics and deepening students' understanding of China's role, Chinese national conditions and political theories with Chinese characteristics.

\section{CONCLUSION}

In the course "Globalization and World Politics", the teaching reform of overseas students focusing on the promotion of the political philosophy of socialism with Chinese characteristics has made remarkable achievements. The successful lessons are summarized as follows:

\section{A. Implant the political ideology of socialism with Chinese characteristics to improve the quality of international students in China}

In order to respond to the national plan to build an Englishteaching curriculum for foreign students in China, to realize the sharing of high-quality course resources, and to build an international course and textbook system for international students, "Globalization and World Politics" is positioned as an internationally high-level course for international students. The course helps students clearly understand the economic, political and diplomatic conditions based on China's national conditions, prospects of major international forces and the international situation. It accurately grasps China's position and role in the international community so students could fully understand opportunities and challenges facing China. Based on the political ideology of socialism with Chinese 
characteristics, the course is helpful to accurately guide the direction of education for overseas students in China, to enable foreign students in China to have a comprehensive and correct understanding of international issues and to enhance the quality of teaching for overseas students.

\section{B. Introduce new ideas to establish a new teaching system}

The course contains three main lines: the major historical events, the core theories, and analysis of international hot issues. The three main lines support the introduction of international political theories in political globalization based on the political ideology of socialism with Chinese characteristics.

Comparative study of behaviors, characteristics and political thoughts of countries and international organizations are conducted, which is supplemented by the teaching materials of China's political system and international participation. The research on international politics has developed into a multi-level and multi-directional system. In the compilation of teaching materials, Chinese context is of great significance which has helped solve the problem of distortion of teaching information so as to enable students to have a full and complete understanding of the whole picture of knowledge. All these methods are taken to write textbook for foreign students in Chinese context.

\section{Inspire students' enthusiasm to optimize the course teaching methods}

The traditional teaching model emphasizes the teacher's role. However, the modern teaching model pays more attention to the students' participation, adopting heuristic teaching, strengthening the interaction between teachers and students to help students recognize the importance of their participation. This requires the transformation of teaching mode from "asking me to learn" toward "I want to learn" to stimulate students' enthusiasm and optimize the new mechanism of curriculum learning. In the teaching reform "Globalization and World Politics", the mode of teaching was transformed from "imparting + seminar" to the teaching mode including case study, discussion, and immersive teaching method. On the basis of traditional teaching, teachers should carry out interactive teaching to enhance students' initiative in understanding the political ideology of socialism with Chinese characteristics, to help students enhance their ability to comprehend and distinguish right from wrong.

\section{REFERENCES}

[1] Wang Jun. The Basic Orientation and Strategy for the International Education in China. China Higher Education Research, vol. 8, pp. 88-92, 2014. (In Chinese)

[2] Zhou Wei. The application and Enlightenment of Case Teaching Method in Foreign Students Education under the Background of "The Belt and Road"-Take "Management" teaching as an example. Pioneering with Science \& Technology Monthly, vol. 20, pp. 44-47, 2017. (In Chinese)

[3] Zhao Shurong. Globalization and World Politics. University of Electronic Science and Technology of China Press, 2017. (In Chinese)

[4] Judith H. Shulman. Case Methods in Teacher Education. East China Normal University Press, 2007.

[5] Li Dingren. Teaching Principle and Method of College Education. Science Press, 1994. (In Chinese)

[6] Seligman M E, Csikszentmihalyi M. Positive Psychology: An Introduction. The American Psychologist, vol. 55, pp. 5-14, 2000.

[7] Robert M. Gagné. The Conditions of Learning. East China Normal University Press, 1999. 